\title{
Image Blocks Model for Improving Accuracy in Identification Systems of Wood Type
}

\author{
Gasim \\ Faculty of Information Technology, \\ Multi Data Palembang Bachelor Program, \\ Palembang, Indonesia \\ Agus Harjoko \\ Dept. of Computer Science and Electronics, \\ Gadjah Mada University, \\ Yogyakarta, Indonesia
}

\begin{abstract}
Image-based recognition systems commonly use an extracted image from the target object using texture analysis. However, some of the proposed and implemented recognition systems of wood types up to this time have not been achieving adequatue accuracy, efficiency and feasable execution speed with respect to practicality. This paper discussed a new method of image-based recognition system for wood type identification by dividing the wood image into several blocks, each of which is extracted using gray image and edge detection techniques. The wood feature analysis concentrates on three parameters entropy, standard deviation, and correlation. Our experiment results showed that our method can increase the recognition accuracy up to $95 \%$, which is faster and better than the previous existing method with $85 \%$ recognition accuracy. Moreover, our method needs only to analyze three feature parameters compared to the previous existing method needs to analyze seven feature parameters, ang thus implying a simpler and faster recognition process.
\end{abstract}

Keywords-image processing; pattern recognition; ANN; wood identification.

\section{INTRODUCTION}

The identification of wood types becomes very important when it related to illegal logging, taxes, and the suitability of the product. This activity is constrained, because the experts in identification of wood are very limited in terms of amount, power, and time.

The experts usually do an initial identification with respect to the macroscopic elements (the impression of touch, smell, weight, color). If there is still doubt, then the expert will observe the microscopic elements in the cross-sectional area, radial cross-section, and cross tangent. This activity uses a magnifying glass (10x).

Its unique features can identify Wood of a particular species. These features include strength, density, hardness, odor, texture and color. Reliable wood identification usually requires the ability to recognize basic differences in cellular structure and wood anatomy.

\author{
Kudang Boro Seminar \\ Dept. of Mechanical and Biosystem Engineering, \\ Bogor Agricultural University (IPB), \\ Bogor, Indonesia \\ Sri Hartati \\ Dept. of Computer Science and Electronics, \\ Gadjah Mada University, \\ Yogyakarta, Indonesia
}

Each species has unique cellular structure that creates differences in wood properties and ultimately determines the suitability for a particular use. Cellular characteristics provide a blueprint for accurate wood identification [2].

Wood is composed of many small cells and its structure is determined by the type, size, shape and arrangement of these cells. The structure and characteristics of wood can vary between species and within the same species. With practice, a small hand lens (10x) can be used to distinguish the different cell types and their arrangements [2].

In the previous research [5], authors used 20 types of wood, using seven characteristics of RGB image, and the six characteristics of image edge detection. This research provide $85 \%$ recognition rate.

In this paper, authors will use the image blocking to identify the type of wood, all type of woods used are similar to previous research [5].

In previous research have showed that the recognition rate varied results with a variety of methods used, include: (1) feature used is the texture analyst added RGB with enlargement 24 times, using five different types of wood [4]. (2) Feature used is the texture analyst; method used is ANFIS, and uses five types of wood [6]. (3) Next research is the comparison of rate recognition based input features with enlarged 24 times, using five different types of wood [9]. (4) The next research using 15 types of wood, texture analysts and RGB as input ANN, using ANNBP, and give the recognition rate 95\% [10]. this value is enough high, due to the number of species that used only 15 types, and test data that are used most of the images are sourced from the same sample with image training.

The research that has been conducted by the authors [5], where 7 features from the gray level image and 6 features from the edge detection image, $85 \%$ could be identified for test results. Recognition rate and the features that used in this research have not been satisfactory. Therefore, the authors propose a method called image blocking. This method expected to reduce the number of features used, and increase the recognition rate. 


\section{PROPOSED METHOD}

The method proposed in this research is block method, i.e. the image is divided into several part, then do extract features in each part. In this research, an image is divided into four blocks. It is related to the microscopic cross section of wood. One character has a pore structure that repeats on each particular size rectangular, although not too similar, and this is characteristic of each type's wood. In addition, the level of magnification used also affects the details of the microscopic and the area has been observed. In this paper, authors use 45 times magnification (optical). Shooting direction is perpendicular to the cross section, and the radius (rays) of the wood is vertical. The details of the steps method is shown in Figure 1.

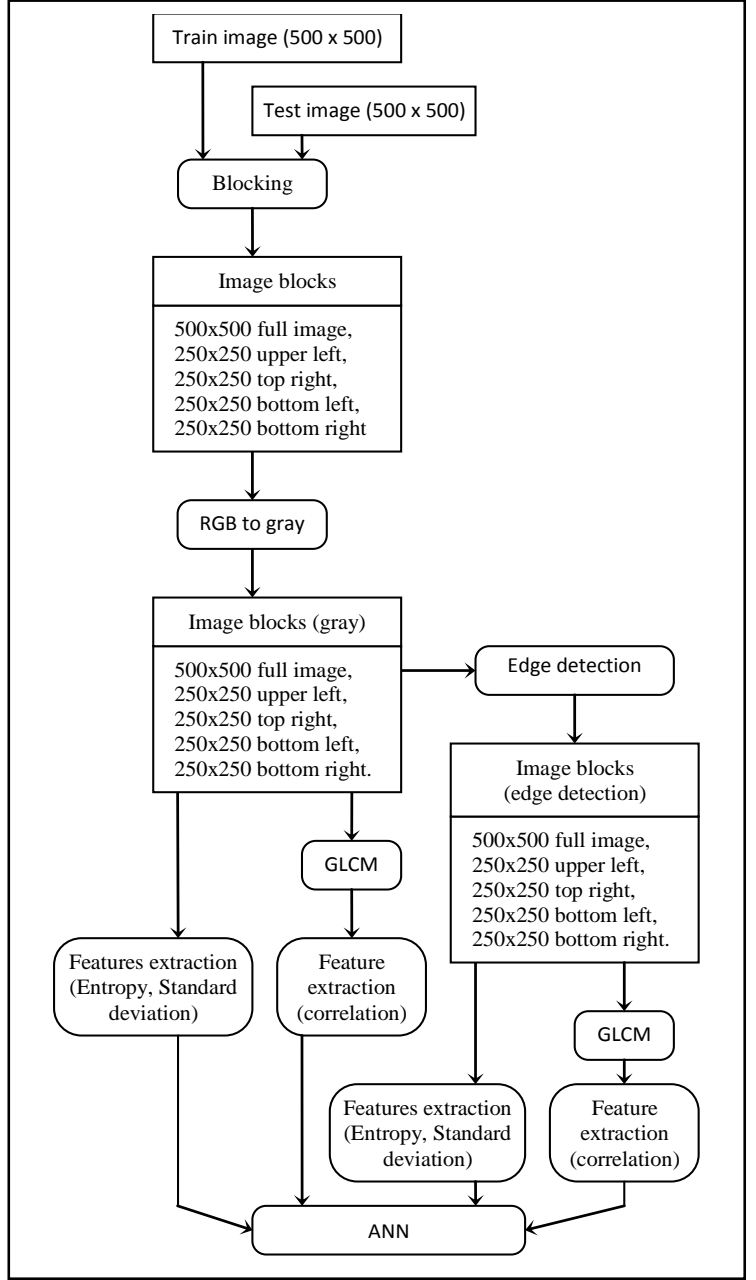

Fig.1. Work steps of the block method.

\section{A. Training Data and Test Data}

The data is a collection of images that has been cut into 500x500 pixels (Figure 5). The image acquisition is conducted using a handheld microscope 1.3 MP (Fig. 2), the vertical lines that exist in the image are the rays. Before being cropped, the image size is $1280 \times 1024$ pixels (Figure 3 ), that is cropped into $500 \times 500$ pixels on a good part.
That is, minimal scratches incision results, and the pore is not closed. This process uses image-editing software (Figure $4)$.

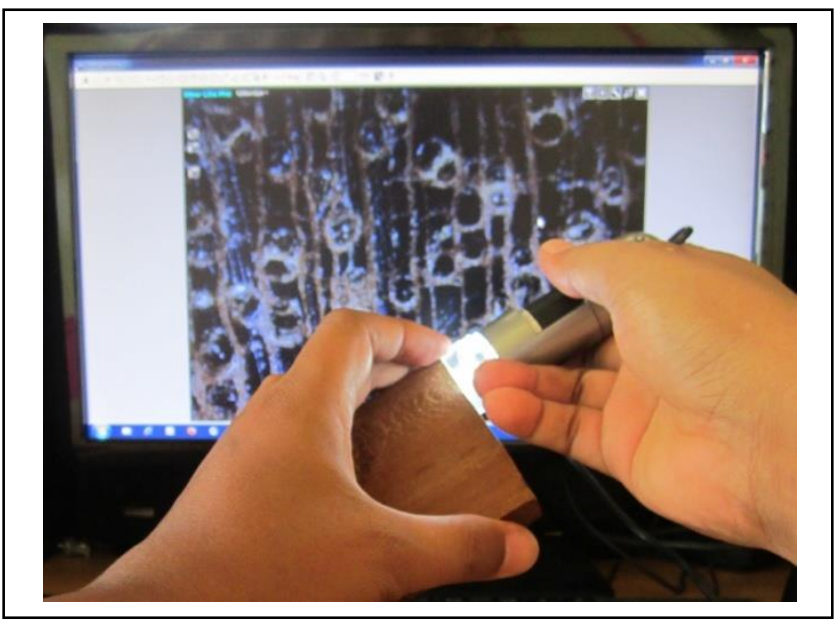

Fig.2. Capturing

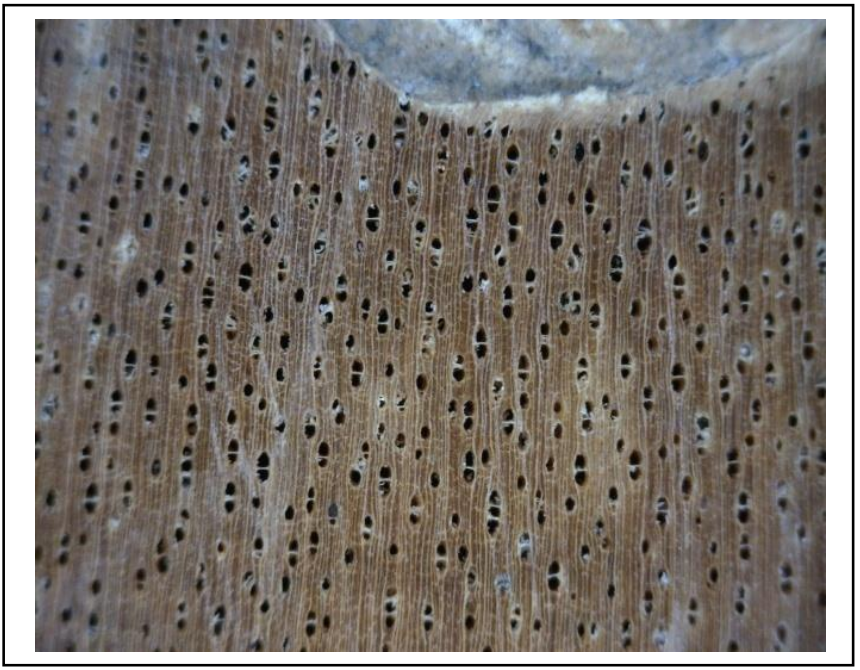

Fig.3. Captured image, $1280 \times 1024$ pixels

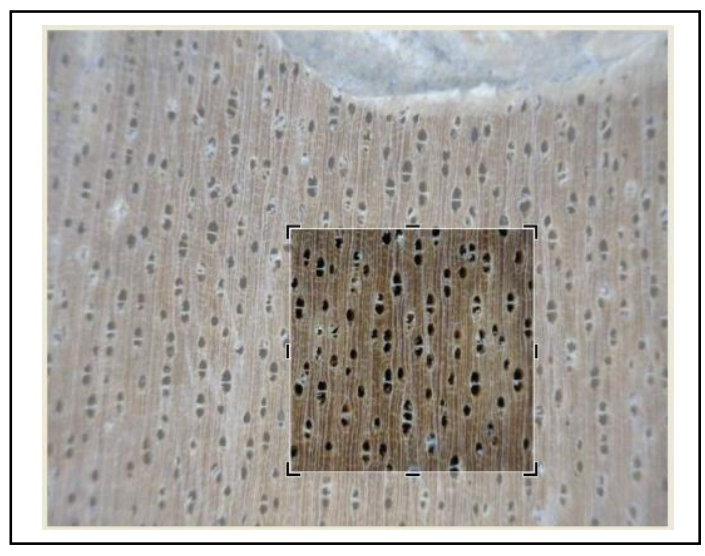

Fig.4. Cropping to 500x500 


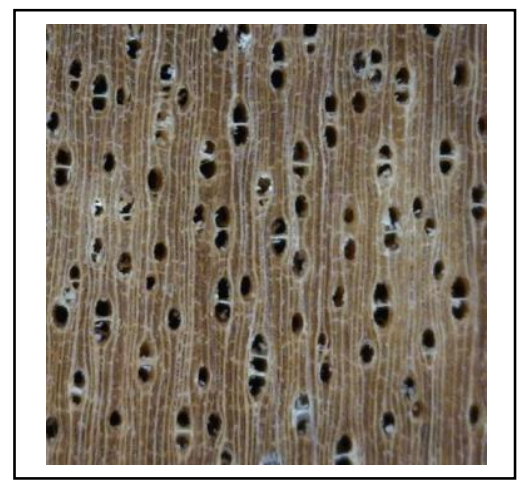

Fig.5. Image 500x500

Wood samples used in this study are presented in Table I. Imagery training consists of 20 types of wood, each type consisting of 100 images derived from some wood samples. So the total is 2,000 image training image. For the test images using five images for each type.

TABLE I. TYPE OF WOOD USED

\begin{tabular}{|r|l|}
\hline No. & \multicolumn{1}{|c|}{ Trade Name (Scientific Name) } \\
\hline 1. & Bakau (Rhizophora apiculata B1.) \\
2. & Cenge (Mastixia trichotoma Bl.) \\
3. & Jabon (anthocepalus cadamba) \\
4. & Jabon merah (Anthocephalus macrophyllus) \\
5. & Kembang semangkok (Scaphium macropodum J.B.) \\
6. & Kruing (Dipterocarpus gracilis Bl.) \\
7. & Kruing (Dipterocarpus kunstleri King) \\
8. & Kulim (Scorodocarpus borneensis Becc.) \\
9. & Mempisang (Mezzetia parviflora) \\
10. & Meranti Kuning (Shorea acuminatissima sym) \\
11. & Meranti Merah (Shorea acuminata) \\
12. & Meranti Merah (Shorea ovalis B1.) \\
13. & Meranti Putih (Shorea Javanica k.ot. val) \\
14. & Merawan (Hopea spp.) \\
15. & Merbau (Intsia bijuga O.K.) \\
16. & Merbau (Intsia palembanica) \\
17. & Mersawa (Anisoptera) \\
18. & Penjalin (Celtis Philippinensis) \\
19. & Perupuk (Lophopetalum javanicum) \\
20. & Rasamala (Hamamelidaceae) \\
\hline
\end{tabular}

\section{B. Blocking}

Blocking is the process of dividing the RGB image into four blocks, each $250 \times 250$ pixels. This method is carried out because of the texture of the cross-sectional image of the wood has a recurring trait on every particular square. Although the texture is not the same between the blocks, but it has an attachment between the turn, so it can be used as feature values.

The rules of blocking are presented in Figure 6. This process is carried out on the whole the image training and test images.

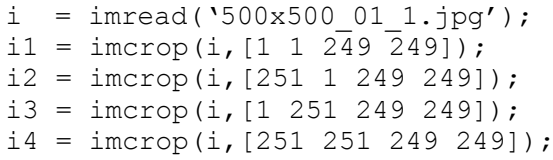

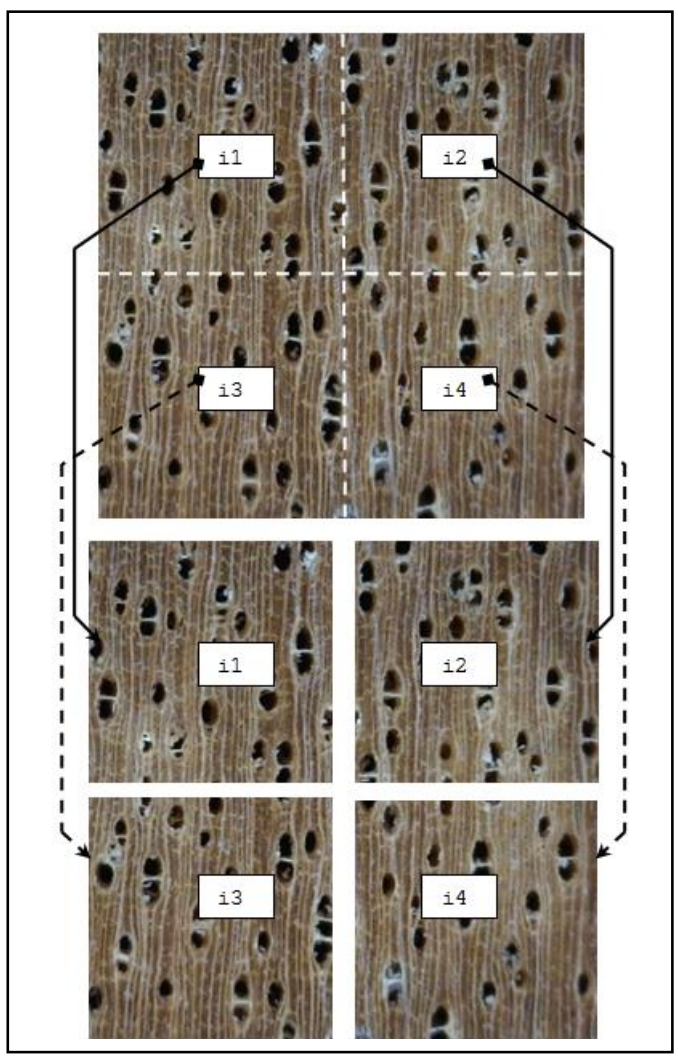

Fig.6. Blocking RGB image

\section{RGB to Gray}

RGB to gray is the process of converting each block RGB image into gray image. This stage is done as needed at a later stage that requires the image of a gray scale.

The rgb2gray converts RGB values to grayscale values by forming a weighted sum of the R, G, and B components [12]

$$
0.2989 * \mathrm{R}+0.5870 * \mathrm{G}+0.1140 * \mathrm{~B}
$$

Matlab function that used to transform the RGB image into gray image is:

$$
\begin{aligned}
& \text { gry_i }=\operatorname{rgb} 2 \operatorname{gray}(i) ; \\
& \text { gry_i1 }=\operatorname{rgb} 2 \operatorname{gray}(i 1) ; \\
& \text { gry_i2 }=\operatorname{rgb} 2 \operatorname{gray}(i 2) ; \\
& \text { gry_i3 }=\operatorname{rgb} 2 \operatorname{ray}(i 3) ; \\
& \text { gry_i4 }=\operatorname{rgb} 2 \operatorname{gray}(i 4) ;
\end{aligned}
$$

\section{Image Blocks (Gray)}

Image blocks is the images converted from RGB images into gray image, which consists of the full image (500x500), top left block $(250 \times 250)$, the top right block $(250 \times 250)$, bottom left block (250x250), and the bottom right block (250x250).

\section{E. Edge Detection}

Edge detection is the process of converting each block of gray image to edge detection image. In this research, the edge detection used is canny. Canny operator is used, because it gives the expected results compared to other operators. 
Edge detection is the approach used most frequently for segmenting images based on abrupt (local) changes in intensity. There are there fundamental steps performed in edge detection [7] :

- Image smoothing for noise reduction.

- Detection of edge points.

- Edge localization.

Cranny's approach is based on three basic objectives [7]:

1) Low error rate

2) Edge points should be well localized

3) Single edge point response

The Matlab function for this process is :

$$
\begin{aligned}
& \text { cny_i = edge (gry_i, 'canny'); } \\
& \text { cny_il = edge(gry_i1,' 'canny'); } \\
& \text { cny_i2 = edge(gry_i2,'canny'); } \\
& \text { cny_i3 = edge(gry_i3, 'canny'); } \\
& \text { cny_i4 = edge(gry_i4, 'canny'); }
\end{aligned}
$$

\section{F. Image Blocks (Edge Detection)}

Image blocks (edge detection) are images converted from gray-level image into image edge detection, which consists of the full image (500x500), top left block (250x250), top right block (250x250), bottom left block (250x250), and bottom right block (250x250).

\section{G. GLCM}

GLCM is a statistical method of examining texture that considers the spatial relationship of pixels is the gray-level cooccurrence matrix (GLCM) [8], also known as the gray-level spatial dependence matrix. The GLCM functions characterize the texture of an image by calculating how often pairs of pixel with specific values and in a specified spatial relationship occur in an image, creating a GLCM, and then extracting statistical measures from this matrix [11]. From this matrix is used to calculate some statistical variables. These statistics provide information about the texture of an image. A number of texture features may be extracted from the GLCM [8].

\section{H. Feature Extraction}

Feature extraction is the process of taking a value or several values of the gray image that will used as the identity of the gray image. The feature extraction Conducted on gray image and edge detection image. The features which taken from each image are entropy, standard deviation, and correlation.

1) Standard deviation: The standard deviation commonly used to measure the distribution of positive and negative values of a member to the average value of all members. To calculate the standard deviation of an image, which is a twodimensional matrix, the following steps were used :

- Calculate the total amount of values all the pixels of a two dimensional matrix $\mathrm{m} \times \mathrm{n}$ pixels.

$$
\text { total }=\sum_{i=1}^{m} \sum_{j=1}^{n} a[i, j]
$$

- Calculate the average values pixel matrix $\mathrm{m} \times \mathrm{n}$ pixels

$$
\text { mean }=\frac{\text { total }}{m \times n}
$$

- Calculate the standard deviation

$$
s t d=\sqrt{\left(\frac{1}{(m \times n)-1}\right) \sum_{i=1}^{m} \sum_{j=1}^{n}(a[i, j]-\text { mean })^{2}}
$$

Matlab function used is :

$$
\begin{aligned}
& \text { std_gray_i }=\text { std2(gry_i); } \\
& \text { std_gray_i1 }=\text { std2(gry_i1); } \\
& \text { std_gray_i2 }=\text { std2(gry_i2); } \\
& \text { std_gray_i3 }=\text { std2(gry_i3); } \\
& \text { std_gray_i4 }=\text { std2(gry_i4); }
\end{aligned}
$$

2) Entropy : Is measure the randomness of the elements of 2D matrix. The entropy is 0 when all $\mathrm{p}_{\mathrm{ij}}$ 's are 0 and is maximum when all $\mathrm{p}_{\mathrm{ij}}$ 's are equal :

$$
\text { ENTROPY }=-\sum_{i=0}^{G-1} \sum_{j=0}^{G-1} P(i, j) \times \log (P(i, j))
$$

Matlab function used is :

$$
\begin{array}{ll}
\text { entropi_gray_i } & \text { entropy(gry_i); } \\
\text { entropi_gray_i1 } & \text { entropy(gry_i1); } \\
\text { entropi_gray_i2 } & \text { entropy(gry_i2); } \\
\text { entropi_gray_i3 }= & \text { entropy(gry_i3); } \\
\text { entropi_gray_i4 } & \text { entropy(gry_i4); }
\end{array}
$$

3) Correlation : Correlation is one of the few variables that are can generate from the GLCM [8]. This variable is used because it gives better results than some other GLCM variables.

We use the following notation [1]:

$G$ is the number of gray levels used.

$\mu$ is the mean value of $P$.

$\mu_{x}, \mu_{y}, \sigma_{x}$ and $\sigma_{y}$ are the means and standard deviations of $P_{x}$ and $P_{y} . P_{x}(i)$ is the $i$ th entry in the marginal-probability matrix obtained by summing the rows of $P(i, j)$ :

Correlation is a measure of how correlated a pixel is to its neighbor over the entire image. Range of values is 1 to -1 , corresponding to perfect positive and perfect negative correlations (6).

CORRELATION $=\sum_{i=0}^{G-1} \sum_{j=0}^{G-1} \frac{\{i \times j\} \times P(i, j)-\left\{\mu_{x} \times \mu_{y}\right\}}{\sigma_{x} \times \sigma_{y}}$

The following feature extraction for gray image:

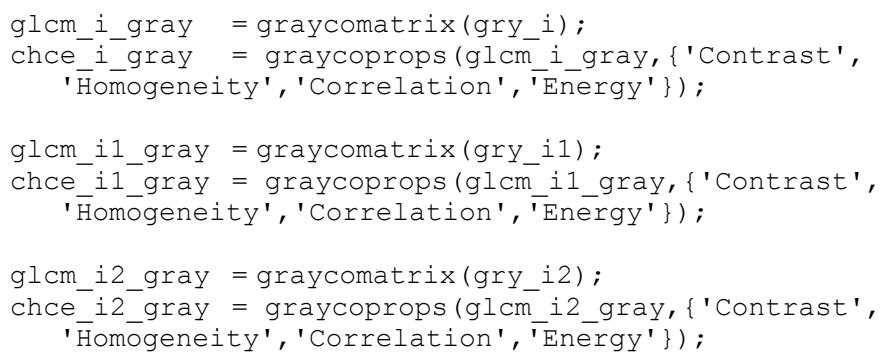


glcm_i3_gray = graycomatrix(gry_i3);

chce i3 gray = graycoprops (glcm i3 gray, \{'Contrast' 'Homogeneity', 'Correlation', 'Energy' \}) ;

glcm_i4_gray = graycomatrix(gry_i4);

chce_i4_gray = graycoprops (glcm_i4_gray, \{'Contrast', 'Homogeneity', 'Correlation', 'Energy' \});

\section{ANN}

In this paper, authors use neural networks to identify the type of wood. It is used because is based on the results of a research journal of pattern recognition; the ANN is the best method. Information of each image for each type of wood is stored in the form of the ANN weights. Weights in the ANN will experience changes during the training period, up to the value of parameter goal is reached. To achieve the expected goal, recognizing $100 \%$ trained image, and the highest test images (95\%), the ANN architecture must be the best. To get the best architecture, it was trial and error on some architecture, i.e. the number of hidden layers and number of neurons of each hidden layer. From the results of experiments on several ANN architectures, the best architecture is the 3 hidden layers, and each hidden layer has 73 neurons. While the number of input neurons is 40 neurons, four are from the full image; image comes from the four blocks. Because image the block there are 4 images derived from image the block there are 16 neurons. The image used is a gray image edge detection and image, so that the number of neurons to 40 . More used the ANN architecture, presented in Table II.

TABLE II. SPECIFICATION OF NEURAL NET WORK

\begin{tabular}{|c|c|}
\hline Characteristic & Specification \\
\hline Architecture, algorithm & 3 hidden layers, back propagation \\
\hline Neuron input & $\begin{array}{l}\text { From gray image: } \\
\text { 1. Full image : entropy, standard } \\
\text { deviation, correlation. } \\
\text { 2. Image block : entropy, standard } \\
\quad \text { deviation, correlation. } \\
\text { From edge detection image : } \\
\text { 1. Full image : entropy, standard } \\
\text { deviation, correlation. } \\
\text { 2. Image block : entropy, standard } \\
\text { deviation, correlation. }\end{array}$ \\
\hline hidden layer & 3 \\
\hline Neuron of hidden layer & $73,73,73$ \\
\hline Neuron of output & 20 (Number of wood) \\
\hline activation function & Sigmoid binary \\
\hline goal & $1 e-24$ \\
\hline learning rate & 0,1 \\
\hline Max epoch & 5000 \\
\hline $\begin{array}{l}\text { Number of image each } \\
\text { wood for data training }\end{array}$ & 100 \\
\hline $\begin{array}{l}\text { Number of image each } \\
\text { wood for data testing }\end{array}$ & 5 \\
\hline
\end{tabular}

Goal value used is 1e-24, because at this value the maximum recognition rate of the test data obtained. While on a smaller goal, i.e. 1e-32, the level recognition to the test data actually decreased. So also with the larger goal of 1e-24.

Matlab function used is :

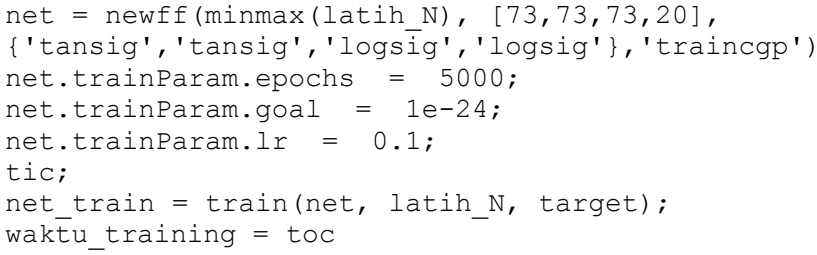

\section{RESULTS}

This experiment, carried out by using 20 types of wood, with a cross-sectional image as the input image. ANN architecture used is three hidden layer, 73 neurons respectively. Tests using 100 test images. for a more complete test results can be seen in Table III.

TABLE III. TESTING RESUlts

\begin{tabular}{|r|l|c|c|}
\hline No. & \multicolumn{1}{|c|}{ Trade Name (Scientific Name) } & $\begin{array}{c}\text { amou } \\
\text { nt of } \\
\text { test } \\
\text { data. }\end{array}$ & $\begin{array}{c}\text { reco } \\
\text { gniz } \\
\text { able }\end{array}$ \\
\hline 1 & Bakau (Rhizophora apiculata B1.) & 5 & 5 \\
\hline 2 & Cenge (Mastixia trichotoma B1.) & 5 & 5 \\
\hline 3 & Jabon (anthocepalus cadamba) & 5 & 5 \\
\hline 4 & Jabon merah (Anthocephalus macrophyllus) & 5 & 4 \\
\hline 5 & Kembang semangkok (Scaphium macropodum J.B.) & 5 & 5 \\
\hline 6 & Kruing (Dipterocarpus gracilis Bl.) & 5 & 5 \\
\hline 7 & Kruing (Dipterocarpus kunstleri King) & 5 & 5 \\
\hline 8 & Kulim (Scorodocarpus borneensis Becc.) & 5 & 5 \\
\hline 9 & Mempisang (Mezzetia parviflora) & 5 & 5 \\
\hline 10 & Meranti Kuning (Shorea acuminatissima sym) & 5 & 4 \\
\hline 11 & Meranti Merah (Shorea acuminata) & 5 & 5 \\
\hline 12 & Meranti Merah (Shorea ovalis B1.) & 5 & 4 \\
\hline 13 & Meranti Putih (Shorea Javanica k.ot. val) & 5 & 5 \\
\hline 14 & Merawan (Hopea spp.) & 5 & 5 \\
\hline 15 & Merbau (Intsia bijuga O.K.) & 5 & 5 \\
\hline 16 & Merbau (Intsia palembanica) & 5 & 4 \\
\hline 17 & Mersawa (Anisoptera) & 5 & 5 \\
\hline 18 & Penjalin (Celtis Philippinensis) & 5 & 5 \\
\hline 19 & Perupuk (Lophopetalum javanicum) & 5 & 4 \\
\hline 20 & Rasamala (Hamamelidaceae) & 5 & 5 \\
\hline & & $\mathbf{1 0 0}$ & $\mathbf{9 5}$ \\
\hline
\end{tabular}

The results of experiment that have been conducted on three of these features is the increasing level of recognition accuracy to $95 \%$. Testing was conducted on 5 images of each type, so there are 100 test images.

\section{CONCLUSION}

An experiment on the identification of types of wood that has been done in this research, has given better results than researches conducted previously authors. In This research has been done on the image the block method, with a combination of image blocks that is divides the image into four equal parts. It aims to reduce the number of features that are used and increasing the recognition to the types of wood. 
The conclusion that authors can write is that:

1) the method can improve the identification of types of wood;

2) and the method can reduce features used in the system of identification type of wood

From the research results, there are opportunities to increase the number of the types of wood, because:

1) this research only use a small number of features;

2) there are still some combinations of blocks that have not been tested;

3) there is an opportunity to test the objects using another magnification level

\section{ACKNOWLEDGMENT}

The authors would like to thank : (1) STMIK Multi Data Palembang (www.mdp.ac.id); (2) the Department of Computer Science and Electronics, Gadjah Mada University (http://mkom.ugm.ac.id) Yogyakarta Indonesia, and Dept. of Mechanical and Biosystem Engineering, Bogor Agricultural University (IPB), Bogor, Indonesia that provides technical support for the research; (3) Department of Forestry Laboratory of Wood Anatomy Bogor Indonesia for timber sample.

\section{REFERENCES}

[1] Albregtsen, F., "Statistical Texture Measures Computed from Gray Level Coocurrence Matrices," Image Processing Laboratory Department of Informatics, University of Oslo, 2008.

[2] Bond B. and Hamner P. "Wood Identification for Hardwood and Soft wood Species Native to Tennese," http://www.utextension.utk.edu/, 2002

[3] Fausett, L., "Fundamentals Of Neural Network Architectures : Algorithm and Applications," Prectice-Hall, Inc., 1994.

[4] Gasim, "The Design and Implementation of an Image-Based Wood Variety Recognition System Using ANN," Proceeding The $9^{\text {th }}$ INTERNATIONAL CONFERENCE on QUALITY in RESEARCH (QiR).Information and Computation Engineering, ISSN : 114-1284, 2006.

[5] Gasim, Harjoko A., Seminar KB., Hartati S. (2013), "Merging Feature Method on RGB Image and Edge Detection Image for Wood Identification", International Journal of Computer Science and Information Technologies (IJCSIT), Vol 4(1), January- February 2013, pp $188-193$

[6] Gasim, Hartati, S., "Arsitektur ANFIS untuk Pengenalan Kavu Berbasis Citra Cross-Section," The International Conterence on Computer and Mathematical Sciences 2010, 29 June 2010 UiTM and UGM Collaboration, Jogjakarta, 2010.
[7] Gonzales, R. C. \& R. E. Woods. "Digital Image Processing." Addison Wesley, Massachusetts, 1992.

[8] Haralick, RM., K. Shanmugam and Itshak Dinstein. "Textural Features For Image Classification," IEEE Transaction On System, Man and Cybernetics. Vol 3, No. 6. 1973.

[9] Harjoko, A., Gasim, "Comparison of Some Features Extraction of Wood," Proceeding The $2^{\text {nd }}$ International Conference on Distributed Frameworks and Applications, Jogjakarta, 2010.

[10] Harjoko, A., Gasim, Rulliaty, S.S., Damayanti, R., "Identification Method for 15 Names of Commercial Wood With Image of Texture Pore as an Input," Proceeding International Conference on Informatics for Development, Jogjakarta, 2011.

[11] Mathwork Inc., "Neural Network Toolbox for Use With Matlab," The Mathwork Inc. Natick, USA, 2012.

[12] Mathwork,"rgb2gray,"www.mathworks.com/help/images/ref/rgb2gray.h tml,- ,2013.

[13] Mathwork,"entropy,"www.mathworks.com/help/images/ref/entropy.htm $1,-, 2013$.

[14] Mathwork,"std2,"www.mathworks.com/help/images/ref/std2.html,,2013.

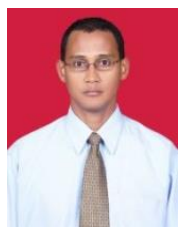

AUTHORS PROFILE

Gasim is a lecturer at the Faculty of Information Technology, Multi Data Palembang, Bachelor Program, Palembang, Indonesia. $\mathrm{He}$ is graduated as Bachelor of Computer in STMIK Bandung, Indonesia. He is received his Master of Computer at Bogor Agricultural University (IPB), Bogor, Indonesia. $\mathrm{He}$ is currently taking his Doctoral Program at the Departement of Computer Science and Electronics, Gadjah Mada University in Yogyakarta,

Indonesia.

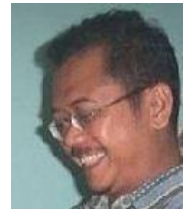

Agus Harjoko is a Associate Professor and Chair of Electronics and Instrumentation Lab. He is graduated from the Electronics and Instrumentation study program, Faculty of Mathematics and Natural Sciences, UGM Yogyakarta, Indonesia. He got M.Sc. and PhD in Computer Science from the University of New Brunswick, Canada.

Kudang Boro Seminar is Professor in Computer

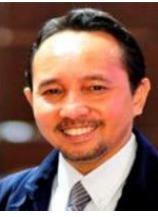
Technology. He is head of laboratory bioinformatics engineering, director of communications and information systems, IPB, and Honorary Member of AFITA (Asian Federation for Information Technology in Agriculture) . He is graduated from Bogor Agricultural University ( IPB) Bogor, Indonesia. He got M.Sc. and $\mathrm{PhD}$ in Computer Science at University of New Brunswick, Canada.

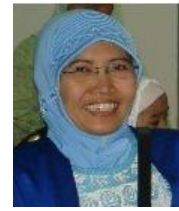

Sri Hartati is a Associate Professor and Chair of Computer Science Graduate Program, Gadjah Mada University, Yogyakarta, Indonesia. She got M.Sc. and PhD in Computer Science Dept, at University of New Brunswick, Canada. 